\title{
研究論文
}

\section{ITER-CS インサート・コイルの分流開始温度特性}

\author{
名原 啓博 ${ }^{* 1, \dagger}$, 齊藤 徹 ${ }^{* 1}$, 諏訪 友音*1, 尾関 秀将 ${ }^{* 1}$, 布谷 嘉彦*1, \\ 高橋 良和 ${ }^{* 1}$, 河野 勝己 ${ }^{* 1}$, 礒野 高明*1
}

\section{Current-sharing Temperature Characteristics of ITER Central Solenoid Insert Coil}

\author{
Yoshihiro NABARA ${ }^{* 1 \dagger}$, Toru SAITO ${ }^{* 1}$, Tomone SUWA $^{* 1}$, Hidemasa OZEKI ${ }^{* 1}$, Yoshihiko NUNOYA $^{* 1}$, \\ Yoshikazu TAKAHASHI ${ }^{* 1}$, Katsumi KAWANO ${ }^{* 1}$ and Takaaki ISONO ${ }^{* 1}$
}

Synopsis: The performance of the ITER central solenoid insert (CSI) conductor was tested in 2015. The current-sharing temperatures $\left(T_{c s}\right)$ were measured over 16,000 electromagnetic cycles, including three thermal cycles between $4.2 \mathrm{~K}$ and room temperature. $T_{c s}$ under the initial magnetization (IM) condition (13 T, $40 \mathrm{kA}$ ) of the CSI conductor not only increased, but also decreased between 6.71 and $6.84 \mathrm{~K}$ against cycling; then $T_{c s}$ became almost constant at $6.74 \mathrm{~K}$. Thus $T_{c s}$ under the IM condition, was approximately $1.5 \mathrm{~K}$ higher than the specification of $5.2 \mathrm{~K}$ throughout the test. The slope of the hoop strain $\left(\varepsilon_{\text {hoop }}\right)$ on the CSI conductor against the electromagnetic force was $1.55 \times 10^{-4} \% \mathrm{~m} / \mathrm{kN}$ (in $\varepsilon_{\text {hoop }}>0$ ) and $1.39 \times 10^{-4} \% \mathrm{~m} / \mathrm{kN}$ (in $\varepsilon_{\text {hoop }}<0$ ). Taking the effect of $\varepsilon_{\text {hoop }}$ into account, the $T_{c s}$ of the CSI under the SULTAN simulated condition (11.5 T, 45.1 kA) was equivalent to that of the SULTAN test after around 10,000 cycles. Before around 10,000 cycles, especially at the initial charge, the $T_{c s}$ of the SULTAN test was lower than that of the CSI test. It is assumed that the hoop strain in the CSI test accelerated a strain relaxation, which increased the $T_{c s}$ from the initial charge. When the strain fully relaxed and $T_{c s}$ stopped increasing after around 10,000 cycles, the $T_{c s}$ of the SULTAN test became equivalent to that of the CSI test. Given this perspective, the CSI test and SULTAN test were consistent. In $\varepsilon_{\text {hoop }}>0$, the absolute value of the effective strain $\left(\varepsilon_{e f f}\right)$ of the CSI test decreased (i.e., $T_{c s}$ increased) against the electromagnetic force $\left(F_{r}\right)$ because the effect of the positive $\varepsilon_{\text {hoop }}$ on the increase in $T_{c s}$ exceeded the effect of the $F_{r}$ on the decrease in $T_{c s}$. The line of $\varepsilon_{e f f}-\varepsilon_{\text {hoop }}$ of the CSI test against $F_{r}$ was nearly symmetric about the $y$-axis $\left(F_{r}=0\right)$. Comparing the $\varepsilon_{e f f}$ $-\varepsilon_{\text {hoop }}$ of the CSI test and the $\varepsilon_{\text {eff }}$ of the SULTAN test, the slopes of the strain against $F_{r}$ were almost the same between the CSI test and SULTAN test before cycling. The $\varepsilon_{\text {eff }}$ of the SULTAN test became close to the $\varepsilon_{\text {eff }}-\varepsilon_{\text {hoop }}$ of the CSI test after cycling. This CSI test demonstrated that mass-produced CS conductors are highly capable of being used in the ITER.

Keywords: ITER, center solenoid, cable-in-conduit conductor, $\mathrm{Nb}_{3} \mathrm{Sn}$, current-sharing temperature (Some figures in this article may appear in colour only in the electronic version.)

\section{1. はじめに}

ITER の中心ソレノイド（Central Solenoid: CS） に用いる $\mathrm{Nb}_{3} \mathrm{Sn}$ 導体は日本が全量の製作を担い、2016 年 2 月の時 点で全量の $51 \%$ （長さ $613 \mathrm{~m}$ の導体を 4 本、918 m の導体 を 21 本）を製作した ${ }^{1)}$ 。製作した導体の性能は、端部を サンプルとして切り出し、スイスにある SULTAN 試験装

Received March 2, 2016

${ }^{* 1}$ 国立研究開発法人 日本原子力研究開発機構

(2016.4.1 より 国立研究開発法人 量子科学技術研究開発機構) 干311-0193 茨城県那珂市向山 801-1

Japan Atomic Energy Agency

(National Institutes for Quantum and Radiological Science and

Technology, from April 1, 2016),

801-1 Mukoyama, Naka, Ibaraki 311-0193, Japan

† E-mail: nabaray.sctg.jaea@gmail.com

DOI : $10.2221 /$ jcsj.51.102
置を用いてこれまで評価している ${ }^{2)}$ 。CS はパルス運転に おける初期励磁（Initial Magnetization: IM）の運転条件 (最高磁束密度 $13 \mathrm{~T}$, 通電電流 $40 \mathrm{kA}$ ) で最も温度マージ ンが小さく、この IM 条件での分流開始温度 $\left(T_{c s}\right)$ の設計 值は $5.2 \mathrm{~K}$ である。しかし、SULTAN 試験装置が発生でき るバックグラウンド磁場は最高 $10.85 \mathrm{~T}$ であり、導体サン プルの通電電流 $40 \mathrm{kA}$ による自己磁場を含めても $11.5 \mathrm{~T}$ なので、IM 条件での $T_{c s}$ を直接測定することができない。 そこで、同等の電磁力が加わる条件として、SULTAN 試 験では $45.1 \mathrm{kA}, 11.5 \mathrm{~T}$ での $T_{c s}$ を測定して来た。一方で、 CS はソレノイド形状なので通電時にフープ力による機械 的歪み（フープ歪み）が加わるが、SULTAN 試験の直状 導体ではこれを再現できない。さらに、SULTAN 試験装 置では最高磁束密度の領域が約 $0.5 \mathrm{~m}$ と狭いことも性能評 価の上で懸念事項であった。そこで、日本の CS モデル。 


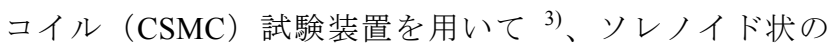
CS インサート（CSI）・コイル（または CSI 導体と呼 ぶ）の IM 条件における $T_{c s}$ を初めて測定し、その設計值 $(5.2 \mathrm{~K})$ に対する裕度や繰返し通電特性を明確にするこ と、またこれまでに得られた SULTAN 試験結果との比較 も行い、実機 CS の運転への見通しを得ることを目的とす る。

なお、2001 年に CS 導体の $T_{C S}$ 測定試験の結果を本誌で 報告したが ${ }^{4)}$ 、その後、導体構造の設計変更を伴いながら $T_{c S}$ 測定結果を論文発表して来たので ${ }^{2,5-8)}$ 、理解を明瞭に するために、ここでその経緯を示す。2000 年に CS モデ ル・コイルを用いた旧 CS インサート・コイルの試験を行 い. IM 条件で $T_{C S}$ が $7.65 \mathrm{~K}$ と大きな裕度を持つことを実 証した ${ }^{4)}$ 。ただ、この時にジャケット管として用いていた Incoloy908 は、923 K から $5 \mathrm{~K}$ までの $\mathrm{Nb}_{3} \mathrm{Sn}$ との熱収縮差 が比較的小さい $(-0.4 \%)$ という利点があるものの、応力 誘起粒界酸化腐食（Stress Accelerated Grain Boundary Oxidation: SAGBO） ${ }^{9,10)}$ による割れのため熱処理後の溶接 が困難であること等から、製作面の合理化を要した。そこ で実機 CS ではジャケット管に JK2LB を用いることとし たが 11,12)、これは Incoloy908 よりも $\mathrm{Nb}_{3} \mathrm{Sn}$ との熱収縮差 が大きい $(-0.8 \%)$ 分、 $T_{c s}$ を低下させる。また、2000 年 の時点では撚線内の 1152 本全てが直径 $0.81 \mathrm{~mm}$, 銅比 1.5 の $\mathrm{Nb}_{3} \mathrm{Sn}$ 素線だったが、合理化・コスト低減を目的とし て、直径 $0.83 \mathrm{~mm}$, 銅比 1.0 の $\mathrm{Nb}_{3} \mathrm{Sn}$ 素線を 576 本と $\mathrm{Cu}$ 線 288 本の撚線とした。その結果、撚線内の超伝導面積は 66\%に減少し、これもまた $T_{c s}$ を低下させる。これら導体 構造の設計変更を経て長さ $3 \mathrm{~m}$ の導体サンプルを製作し、 SULTAN 試験を行ったところ、 $T_{c s}$ が繰返し通電回数に対 してほぼ直線的に低下し続けることが示された ${ }^{5,6)}$ 。定常 運転を行う $\mathrm{TF}$ コイルと異なり、CS はパルス運転を行う ため、この $T_{c s}$ の直線的な低下を抑制する必要が生じた。 そして、1 次から 4 次までの然りピッチを従来の半分程度 に短くすることで $T_{c s}$ の低下を抑制できることが分かり 7,8)、これにより導体構造の設計を最終化して、導体の量 産を開始した ${ }^{2,13)}$

\section{2. フープ歪み}

\section{1 測定方法}

歪ゲージの設置方法を Fig. 1 に示す。歪ゲージは導体長 手方向の一軸ゲージであり、共和電業製の既製品（型番 : KFL-5-350-C1-16）の絶縁ベースをより広くしたオーダー メイド品（型番：SKF-28877）である。導体外周の対地絶 縁（厚さ約 $4 \mathrm{~mm}$ ）を一部剥ぎ、ジャケット材の表面に接 着剂（型番：EP-270）で直接貼り付けた。また、磁場・温 度の効果を除去するため、隣接する場所にダミーゲージを 取り付け、アクティブ・ダミーの 2 ゲージ法による測定を 行った。

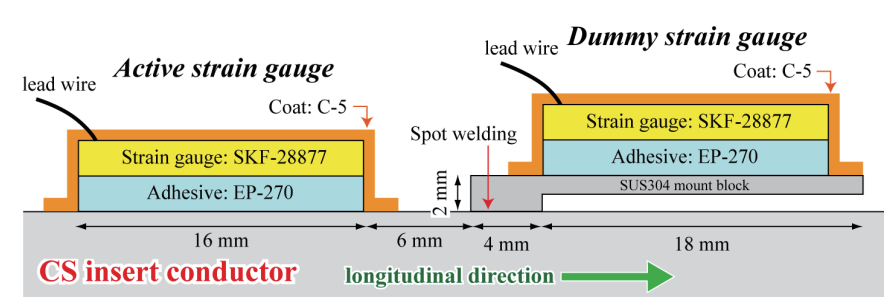

Fig. 1 Active strain gauge and dummy strain gauge on the CS insert conductor.

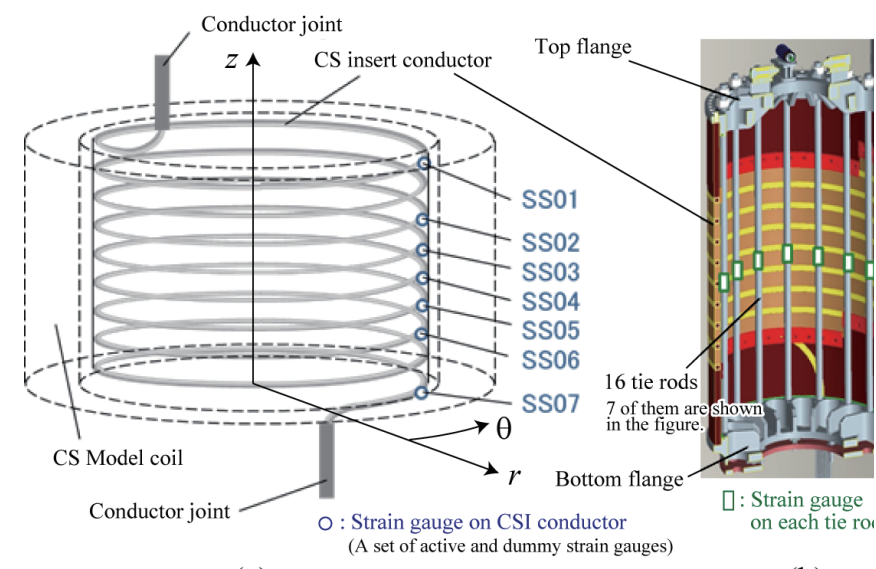

(a)

(b)

Fig. 2 Location of seven strain gauges and cylindrical coordination on the CS insert conductor (a) and top flange, bottom flange, and 16 tie rods with strain gauges inside the CS insert conductor (b).

CSI 導体のフープ歪みは、Fig. 2 の SS01〜SS07 で示す 7 箇所で計測した（歪ゲージはソレノイドの外周側の面に設 置した）。磁束密度の高い領域にある SS02〜SS06 はほぼ 同じフープ歪み值が得られており、長さ約 $19 \mathrm{~m}$ に亘って ほぼ均一な歪みが加わっていることを確認した。以降に示 すフープ歪みは、最も高磁場の位置にある SS04 の值を用 いるものとする。なお、本稿では電磁力等の方向を Fig. 2 に示す円筒座標で述心、電磁力が CSI 導体を $r$ 方向に拡張 する（ $\theta$ 方向のフープ歪みが正值になる）方向の通電を正 值として順通電（または順励磁）と呼び、 $r$ 方向に圧縮す る（ $\theta$ 方向のフープ歪みが負值になる）方向の通電を負值 として逆通電（または逆励磁）と呼ぶこととする。

\section{2 電磁力に対するフープ歪み}

IM 条件（13 T, $40 \mathrm{kA）は、まず} \mathrm{CS} \mathrm{モデル・コイルを}$ 単独で $45 \mathrm{kA}$ まで通電した後、CSI 導体を $40 \mathrm{kA}$ まで通電 する。この間の各通電電流とフープ歪みの経時変化を Fig. 3 に示す。CS モデル・コイルの通電電流を $45 \mathrm{kA}$ に 上げることでフープ歪みが $0.026 \%$ まで上昇したが、この 間は CSI 導体に通電していないので、CSI 導体に直接電磁 力は加わっておらず、本来、フープ歪みは増加しないはず である。CS モデル・コイルと CSI 導体はフランジを通じ て繋がっており、CS モデル・コイルの自己磁場による変 形が CSI 導体も変形させることは構造上あり得るが、設 


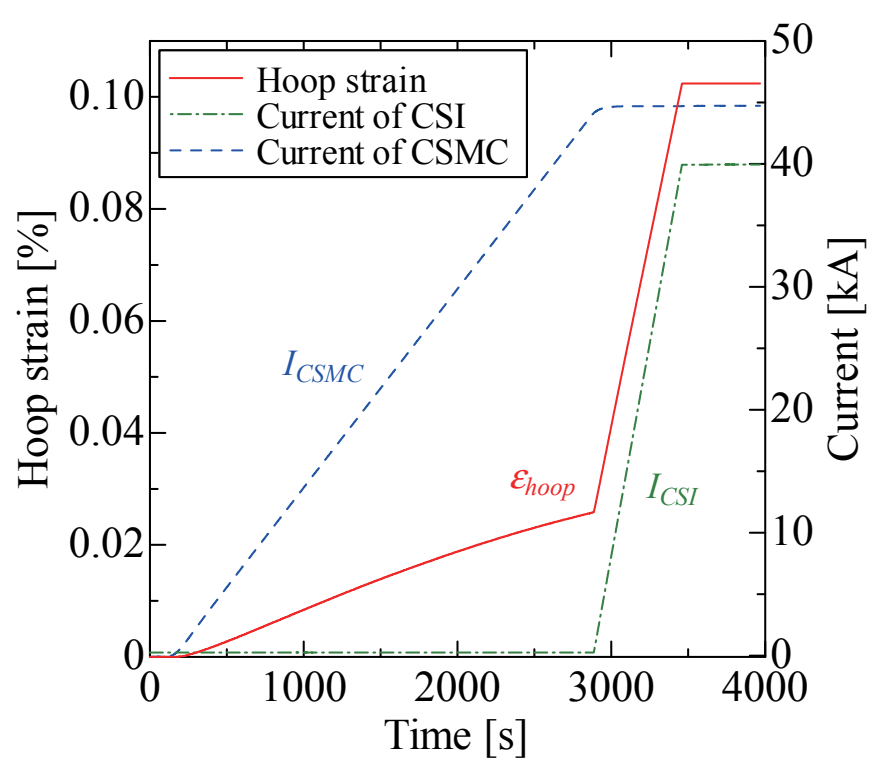

Fig. 3 Hoop strain and currents of CSI conductor and CS model coil $($ CSMC) against time (measured time step $=1 \mathrm{~s}$ ).

計上、この影響は小さいと予想される。また、歪みゲージ は極低温域では温度依存性が大きいので、CS モデル・コ イルの単独励磁による CSI 導体の交流損失が、アクティ ブとダミーの歪みゲージに温度差を生じさせる可能性もあ るが（ダミー歪みゲージはジャケット表面に直接貼り付け ていないため）、歪みゲージの近傍にある温度計で、特に 大きな温度上昇は見られなかったため、本測定では温度上 昇による影響の可能性は低いと思われる（ただ、この可能 性もゼロではないため、本試験で使用した歪みゲージの磁 場中での温度感受性の度合いに関して調べる必要がある）。 おそらく、磁場の影響で見かけの歪みが発生したのではな いかと思われるため、CSI 導体に通電する直前（Fig. 3 で 2886 s）のフープ歪み值をゼロと仮定して、フープ歪みを 評価することとした（この妥当性は今後検証を進める）。 なお、磁場の影響でフープ歪みのゼロ点が変わるのであれ ば、CSI 導体の通電で生じる自己磁場によってもゼロ点が 変わることになる。そこで、CS モデル・コイルの通電に よるゼロ点シフトと同じ割合（12.5 T で $0.026 \%)$ を仮定 すると、CSI 導体の $40 \mathrm{kA}$ 通電（自己磁場は歪みゲージ位 置で $0.37 \mathrm{~T}$ ）によるゼロ点シフトは $0.00077 \%$ と推測され る。これは $0.026 \%$ に対してかなり小さいので、無視して も差し支えないレベルと言える。

上述のゼロ点調整を施した、 $r$ 方向の電磁力 $\left(F_{r}\right)$ に対 するフープ歪み $\left(\varepsilon_{\text {hoop }}\right)$ の測定結果を Fig. 4 に示す（ $\varepsilon_{\text {hoop }}$ は $\theta$ 方向の歪みだが、第 4 章で議論する電磁力が $F_{r}$ であり、 これに $\varepsilon_{\text {hoop }}$ を利用するため、Fig. 4 の横軸も $F_{\theta}$ でなく $F_{r}$ とした）。 $F_{r}>0$ は拡張方向の通電を表し、まず CS モデ ル・コイルを単独で $43.7 \mathrm{kA}$ まで通電した後、CSI 導体の 通電電流を $0 \mathrm{kA}$ から $59.9 \mathrm{kA}$ まで上げて $\varepsilon_{\text {hoop }}$ を測定した。 $F_{r}<0$ は圧縮方向の通電を表し、まず CS モデル・コイル

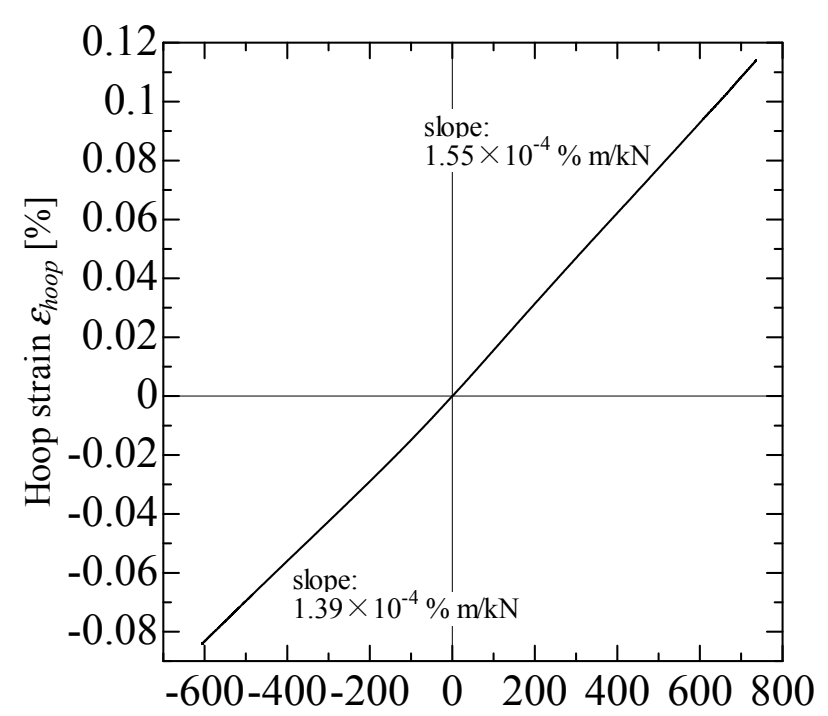

Radial electromagnetic force $F_{r}=B_{z}{ }^{a v g} I[\mathrm{kN} / \mathrm{m}]$

Fig. 4 Measured hoop strain against radial electromagnetic force (measured data: 1384 plots in $F_{r}>0,1453$ plots in $\left.F_{r}<0\right)$.

を単独で $44.7 \mathrm{kA}$ まで通電した後、CSI 導体の通電電流を $0 \mathrm{kA}$ から-49.5 kA まで上げて $\varepsilon_{\text {hoop }}$ を測定した。 $F_{r}$ は撚線 断面の平均磁束密度 $\left(B_{z}{ }^{a v g}\right)$ （自己磁場を含む）を用いて

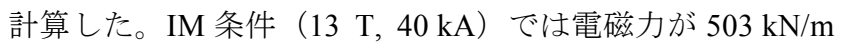
$\left(B_{z}{ }^{a v g}=12.6 \mathrm{~T}\right)$ 、フープ歪みが $0.0781 \%$ だった。順励磁で は $1.55 \times 10^{-4} \% \mathrm{~m} / \mathrm{kN}$ の勾配であるのに対し、逆励磁では $1.39 \times 10^{-4} \% \mathrm{~m} / \mathrm{kN}$ と 1 割小さい。なお、2000 年に実施した 旧 CS インサート・コイルの試験でも、順励磁で $1.99 \times 10^{-4}$ $\% \mathrm{~m} / \mathrm{kN}$ の勾配、逆励磁で $1.65 \times 10^{-4} \% \mathrm{~m} / \mathrm{kN}$ の勾配と、や はり後者の方が小さい結果が得られている ${ }^{14)}$ (本 CSI 試 験に比べて勾配が大きいのは、第 1 章で述べた導体構造の 設計が変わったためと考えられる）。この励磁方向によっ て勾配が異なった原因は下記のように推測する。Fig. 2 に 示した通り、CSI 導体には上下にフランジがあり、円周方 向に 16 本配置したタイロッドで上下のフランジを予め $z$ 方向に圧縮しておくことで、CSI 導体の通電に伴う変形を 抑制している。順励磁の場合、CSI 導体は $r$ 方向に拡張す ると同時に（体積を一定に保とうとして） $z$ 方向に収縮す るため、タイロッドに取り付けた $z$ 方向の歪ゲージの測定 值 $\left(\varepsilon_{z}^{\text {tie rod }}\right)$ は通電前の值から減少し（IM 条件において $\Delta \varepsilon_{z}^{\text {tie rod }}=-0.009 \%$ ）、CSI 導体の $r$ 方向膨張に対する上下 フランジからの抑制効果は小さくなる。一方、逆励磁の場 合、CSI 導体は $r$ 方向に収縮すると同時に $z$ 方向に延びる ため、タイロッドの $z$ 方向歪みは増加し（13 T, $-40 \mathrm{kA}$ で $\Delta \varepsilon_{z}^{\text {tie rod }}=0.009 \%$ ）、CSI 導体の $r$ 方向収縮に対する上下フ ランジからの抑制効果は大きくなる。この通電方向による 上下フランジからの $r$ 方向変形の抑制効果の違いが、

Fig. 4 における勾配の違いの原因ではないかと推測され、 今後、構造解析を行って検討する予定である。 
なお、歪ゲージはジャケット表面（ソレノイドの外周 側）に貼り付けてあるため、その測定值は内部の撚線に加 わっているフープ歪みとは若干異なるはずである。そこで、 ジャケット表面と内部の撚線でフープ歪みがどれくらい異 なるかを解析的に試算した。導体はジャケット管と撚線と 絶縁材から成る異方性のある物であるため、正確には ANSYS などを用いた詳細な構造解析を行う必要があるが、 ここではジャケット表面と撚線のフープ歪みの差異を試算 することを目的とし、Fig. 5 (a)の単純な材料力学モデルを 考えた。 $\theta$ 方向と $z$ 方向に一様な円筒に電磁力 $J_{\theta} B_{z}$ が加わ る場合、力の釣り合いから

$$
\sigma_{\theta}-\sigma_{r}-r \frac{d \sigma_{r}}{d r}-J_{\theta} B_{z} r=0
$$

が成り立つ。これを境界条件

$$
\left.\sigma_{r}\right|_{r=r_{1}, r_{2}}=0, \quad \int_{r_{1}}^{r_{2}} \sigma_{z} \cdot 2 \pi r d r=P_{z}
$$

の下で解くと、 $\varepsilon_{r}, \varepsilon_{\theta}, \varepsilon_{z}$ は下式となる。

$\epsilon_{r}=\frac{J_{\theta} \alpha}{8(1-\nu) E}\left\{-3(1+\nu)(1-2 \nu) r^{2}+(3-5 \nu)\left(r_{1}^{2}+r_{2}^{2}\right)-(1+\nu)(3-2 \nu) \frac{r_{1}^{2} r_{2}^{2}}{r^{2}}\right\}-\frac{\nu P_{z}}{E \pi\left(r_{2}^{2}-r_{1}^{2}\right)}$

$+\frac{J_{\theta} \beta}{3(1-\nu) E}\left\{-2(1+\nu)(1-2 \nu) r+\left(2-3 \nu-\nu^{2}\right) \frac{r_{1}^{2}+r_{1} r_{2}+r_{2}^{2}}{r_{1}+r_{2}}-(1+\nu)(2-\nu) \frac{r_{1}^{2} r_{2}^{2}}{\left(r_{1}+r_{2}\right) r^{2}}\right\}$

$\epsilon_{\theta}=\frac{J_{\theta} \alpha}{8(1-\nu) E}\left\{-(1+\nu)(1-2 \nu) r^{2}+(3-5 \nu)\left(r_{1}^{2}+r_{2}^{2}\right)+(1+\nu)(3-2 \nu) \frac{r_{1}^{2} r_{2}^{2}}{r^{2}}\right\}-\frac{\nu P_{z}}{E \pi\left(r_{2}^{2}-r_{1}^{2}\right)}$

$+\frac{J_{\theta} \beta}{3(1-\nu) E}\left\{-(1+\nu)(1-2 \nu) r+\left(2-3 \nu-\nu^{2}\right) \frac{r_{1}^{2}+r_{1} r_{2}+r_{2}^{2}}{r_{1}+r_{2}}+(1+\nu)(2-\nu) \frac{r_{1}^{2} r_{2}^{2}}{\left(r_{1}+r_{2}\right) r^{2}}\right\}$

$\epsilon_{z}=-\frac{J_{\theta} \alpha \nu}{2 E}\left(r_{1}^{2}+r_{2}^{2}\right)-\frac{2 J_{\theta} \beta \nu}{3 E} \frac{r_{1}^{2}+r_{1} r_{2}+r_{2}^{2}}{r_{1}+r_{2}}+\frac{P_{z}}{E \pi\left(r_{2}^{2}-r_{1}^{2}\right)}$

ここで、Fig. 4 の $\boldsymbol{\varepsilon}_{\text {hoop }}$ は、上下フランジからの力 $\left(P_{z}\right)$ を 印加した後の電磁力ゼロの状態を基準とした值なので、

$\varepsilon_{\text {hoop }}=\varepsilon_{\theta}\left(r, B_{1}, B_{2}, I, P_{z}\right)-\varepsilon_{\theta}\left(r, 0,0,0, P_{z}\right)$ と、ゼロ点をシフ 卜させる必要があることに注意を要する（ $\varepsilon_{r}$ と $\varepsilon_{z}$ も同様で ある）。ただ、 $P_{z}=0$ であれば $\varepsilon_{\theta}\left(r, 0,0,0, P_{z}\right)=0$ なので $\varepsilon_{\text {hoop }}=\varepsilon_{\theta}$ である。なお、前述の通り、本モデルは実際の導 体をかなり簡略化した物なので、各種物性值から本解析で $r=r_{2}$ での $\varepsilon_{\text {hoop }}$ の実測值を再現することは難しい。そこで、 $r=r_{2}$ での $\varepsilon_{\text {hoop }}$ が IM 条件での実測值 $(0.0781 \%)$ に一致す るようにヤング率 $(E)$ の值を選ぶこととし、175 GPa と した。ポアソン比 $(v)$ は $0.3 、 P_{z}$ は-6 MN とした。この ときの IM 条件における各歪みの $r$ 方向分布を Fig. 5 (b)に 示す。Fig. 5 (b)に示す通り、一般的な圧力容器と同様、内 周 $\left(r=r_{l}\right)$ で $\varepsilon_{\theta}$ が $\left(\sigma_{\theta}\right.$ も) 最大になる（逆通電時も $r=r_{l}$ で $\varepsilon_{\theta}$ 及び $\sigma_{\theta}$ の絶対值が最大になる）。導体中心 $\left(r=\left(r_{1}+r_{2}\right) / 2\right)$ でのフープ歪みは外周 $\left(r=r_{2}\right)$ に比べて 1.045 倍に高くなっていることから、撚線に加わっている フープ歪みは Fig. 4 の $\varepsilon_{\text {hoop }}$ の 1.045 倍と推測できる。ただ、 この倍率は小さく、また正確には詳細な構造解析が必要で あるため、本論文では歪ゲージで測定した Fig. 4 の $\varepsilon_{\text {hoop }}$ の 值をそのまま撚線のフープ歪みと考え、以下の議論に用い ることとする。
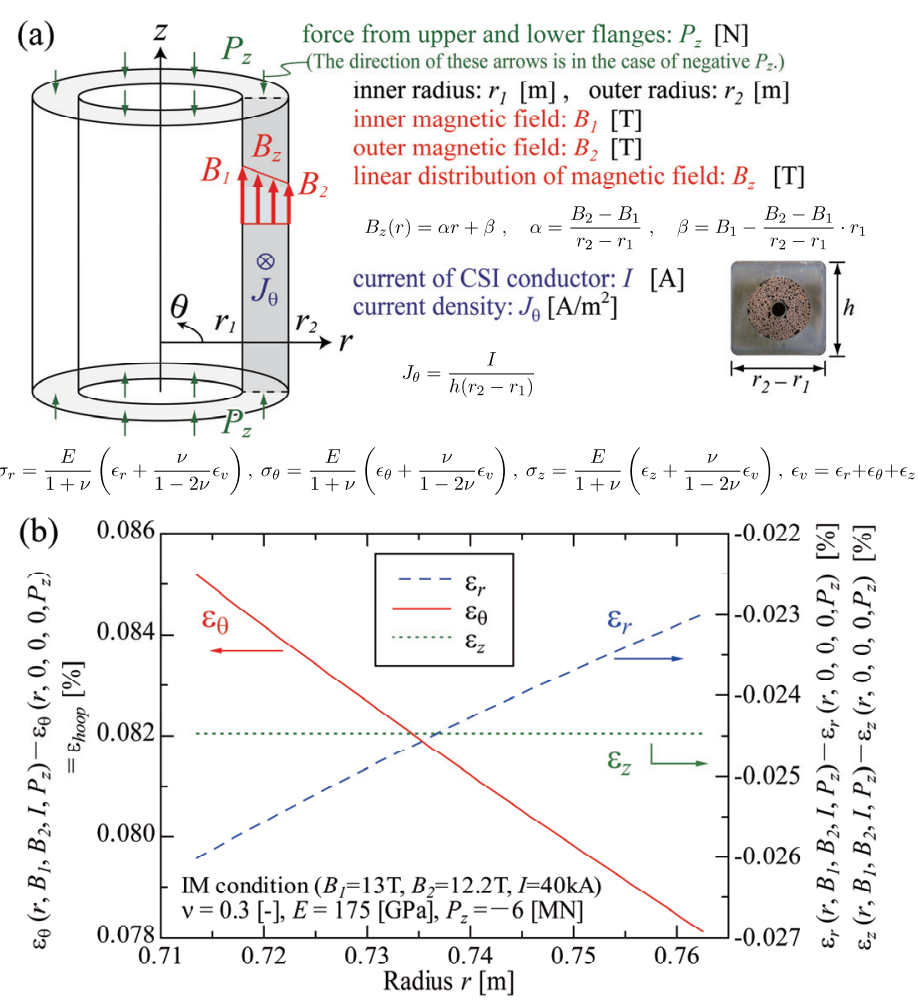

Fig. 5 Simplified cylindrical model for CSI conductor (a) and calculated strains against radius under IM condition (b).

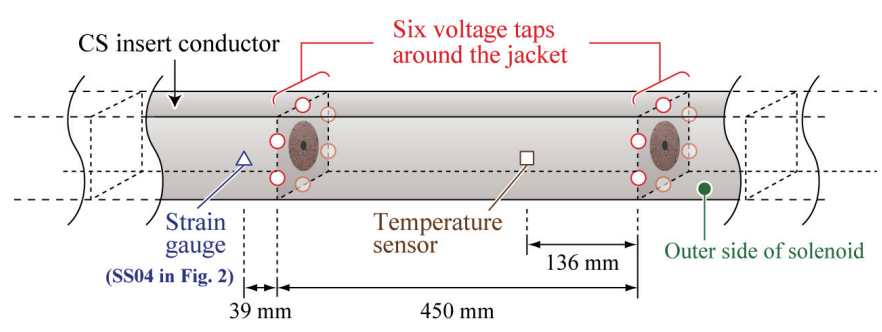

Fig. 6 Allocation of sensors for voltage, temperature, and strain on the CS insert conductor.

\section{3. 分流開始温度}

\section{1 測定方法}

分流開始温度 $\left(T_{c s}\right)$ の測定試験では、通電電流と磁束密 度を一定に保った状態で、導体内に流す冷媒の温度を段階 的に上げることで、各温度における発生電圧のプロットを 得る。Fig. 6 に電圧タップと温度計と歪ゲージ（Fig. 2 の SS04）の位置関係を示す。電圧は最高磁場領域内に設置し た電圧タップ（長さ $0.45 \mathrm{~m}$ ) で計測しており、電圧が $4.5 \mu \mathrm{V}$ （単位長さあたりの電圧として $10 \mu \mathrm{V} / \mathrm{m}$ ) となる温 度を $T_{c s}$ と定義した。温度計は電圧タップ間に、歪ゲージ は電圧タップに隣接した位置（導体長手方向に $39 \mathrm{~mm}$ 離れ た位置）に設置してあり、これらはソレノイドの外周側の 面にある。Fig. 4 のフープ歪みはこの歪ゲージの測定值で ある。一方、電圧タップに関しては、導体断面内の電流分 
布が均一とは限らないことから、ジャケット管の周囲に 6 組の電圧タップを配置しており、電圧はこれらの平均值を 用いて評価した。

CS は ITER でパルス運転を行うため、 $T_{c s}$ の繰返し通電 特性が重要となる。本 CSI 試験では、撚線に加わる電磁力 が最も高いプラズマ燃焼終了（End of Burn: EOB）時の条 件（12.5 T, 45.1 kA）で繰返し通電を行った（EOB 条件で は $542 \mathrm{kN} / \mathrm{m}$ の電磁力が加わる)。まず $\mathrm{CS}$ モデル・コイル を $42.8 \mathrm{kA}$ で永久電流モードにし、CSI 導体に $12 \mathrm{~T}$ を印加 した状態で、CSI 導体の通電電流を $0 \mathrm{kA}$ から $45.1 \mathrm{kA}$ 間を 上げ下げして繰返し通電を行う。その間に適宜、 $T_{c s}$ を測定 した。ここで、CS モデル・コイルの永久電流はジョイン 卜抵抗によって徐々に減衰するため、下限值（38.7 kA）を 下回らないよう、適宜、永久電流モードを解除して再び $42.8 \mathrm{kA}$ に上げている。CSI 試験では繰返し通電は 16000 回 行った。

また、ITER の CS は 6 モジュールで構成されるが、スペ アを含めて 7 モジュール製作する。このスペアとの交換や メンテナンスを行う際は CS を室温まで昇温するため、昇 温・再冷却に対する $T_{c S}$ の変化を調べる必要がある。そこ で、5000 回、8000 回、10000 回の繰返し通電時に $T_{c s}$ を測 定した後、一旦 CSI 導体のみ室温まで昇温し、その後、再 び冷却して $T_{c s}$ を測定した。 $T_{c s}$ は IM 条件の他、SULTAN 試験結果との比較を目的として SULTAN 模擬条件（11.5 T, $45.1 \mathrm{kA})$ などで測定した。

\section{2 繰返し通電特性}

16000 回の繰返し通電と 3 回の昇温・再冷却に対する $T_{c s}$ の変化を Fig. 7 に示す。この図には IM 条件（13 T, $40 \mathrm{kA）}$ での $T_{c s}$ と、SULTAN 模擬条件（11.5 T, 45.1 kA）での $T_{c s}$ に 加え、比較のため 2014 年に SULTAN 試験（20000 回の繰 返し通電と 4 回の昇温・再冷却を実施）で測定した $T_{c S}$ も 示す。CSI 試験では IM 条件の $T_{c S}$ の測定頻度が最も多いの で、まず IM 条件の繰返し通電特性を述べる。最初の 5000 回までの繰返し通電で、多少の上下はあるものの、 $T_{c s}$ はほ ぼ一定であり、その後の 1 回目の昇温・再冷却で $T_{c s}$ が $0.11 \mathrm{~K}$ 上昇した。その後の 8000 回までの繰返し通電では、

$T_{c s}$ が-2.18 $\times 10^{-5} \mathrm{~K} /$ cycle で緩やか低下し、その後の 2 回目の 昇温・再冷却で $T_{c s}$ が $0.07 \mathrm{~K}$ 上昇した。その後の 10000 回 までの繰返し通電で $T_{c s}$ が- $1.29 \times 10^{-5} \mathrm{~K} /$ cycle でより緩やか に低下し、その後の 3 回目の昇温・再冷却で $T_{c s}$ が $0.04 \mathrm{~K}$ 低下した。その後の 16000 回までの繰返し通電では $T_{c s}$ が $6.74 \mathrm{~K}$ で一定化した。以上の結果から、16000 回の繰返し 通電と 3 回の昇温・再冷却の間、 $T_{c s}$ は $6.71 \mathrm{~K}$ から $6.84 \mathrm{~K}$ の間で増減した後に $6.74 \mathrm{~K}$ で一定化し、設計值の $5.2 \mathrm{~K}$ に 比べて $1.5 \mathrm{~K}$ 以上の裕度を維持し続けることを実証した。 なお、第 1 章で触れたが、1 次から 4 次の撚りピッチを約 半分に短くする前の導体では、 $T_{c s}$ は繰返し通電に対して $-4.39 \times 10^{-5} \mathrm{~K} /$ cycle の勾配でほぼ直線的に低下し続けた ${ }^{6)}$ 。

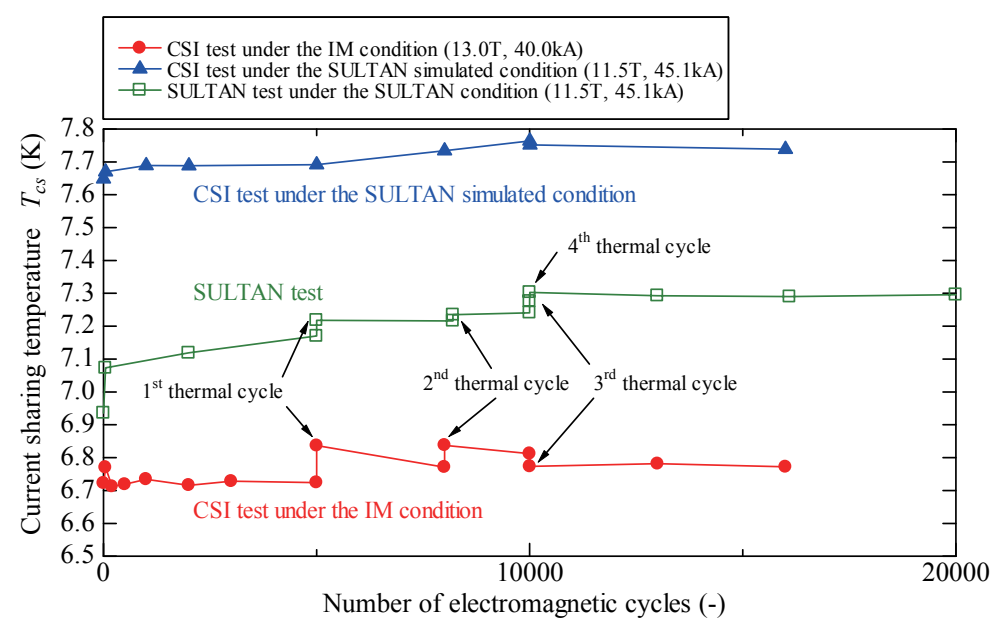

Fig. 7 Current-sharing temperature against number of electromagnetic cycles, including three warm-up and cool-down cycles.

CSI 試験ではこのような高い低下率で継続的に $T_{c s}$ が低下し 続ける現象は見られず、撚りピッチを短くした効果が表れ ていると言える。

\section{3 SULTAN 試験結果との比較}

次に、CSI 試験での SULTAN 模擬条件（11.5 T, 45.1 kA） の $T_{c S}$ と、SULTAN 試験での $T_{c s}$ を比較する（なお、CSI 試 験は試験期間が限られていたため、IM 条件に比べて SULTAN 模擬条件の $T_{c s}$ 測定頻度は低く、したがって Fig. 7 でのデータのプロット数が少ない)。CSI 試験では正のフー プ歪み（SULTAN 模擬条件で $0.0770 \%$ ）が加わるため、 $T_{c s}$ はそれに相当する $0.5 \mathrm{~K}$ (後述の $I_{c}(B, T, \varepsilon)$ 式を用いて見積 もることができる) ほど SULTAN 試験よりも高くなり得 る。したがって、Fig. 7 で CSI 試験の SULTAN 模擬条件の $T_{c s}$ を全体的に $0.5 \mathrm{~K}$ 下げることで、 10000 回以降の $T_{c s}$ に関 して SULTAN 試験の結果に近くなるのは理に適っている。 ただ、CSI 試験の $T_{c S}$ を $0.5 \mathrm{~K}$ 下げても、10000 回未満の繰 返し通電の間は SULTAN 試験の方が $T_{c s}$ が低い。特に最初 の通電時の $T_{c s}$ は、CSI 試験が $7.65 \mathrm{~K}$ なのに対して SULTAN 試験は $6.94 \mathrm{~K}$ と、フープ歪みの分（0.5 K）を差 し引いても $0.21 \mathrm{~K}$ も低い。このため、 $T_{c s}$ の最初の通電時 の值からの上昇幅 $\left(\Delta T_{c s}\right)$ としては、CSI 試験では 10000 回の繰返し通電で $\Delta T_{c S}=0.11 \mathrm{~K}$ だったのに比べ、SULTAN 試 験では $\Delta T_{c s}=0.31 \mathrm{~K}$ と約 3 倍も大きい。また、（2 度目の $T_{c s}$ 測定である） 50 回の繰返し通電時の $T_{c s}$ 測定では、 SULTAN 試験は $\Delta T_{c s}=0.14 \mathrm{~K}$ だったのに対し、CSI 試験は $\Delta T_{c s}=0.02 \mathrm{~K}$ と非常に小さいことも両試験の大きな違いであ る。以上のことから、繰返し通電回数が少ない間、 SULTAN 試験は CSI 試験よりも $T_{c s}$ が低いが、繰返し通電 を経ると両者はほぼ同等の $T_{c s}$ になったと言える。これは 第 4 章で有効歪み $\left(\varepsilon_{\text {eff }}\right)$ を議論する中で、SULTAN 試験の 
$\varepsilon_{e f f}$ と CSI 試験の $\varepsilon_{e f f} \varepsilon_{h o o p}$ を比較すると、繰返し通電前は SULTAN 試験が CSI 試験に比べて絶対值が大きいが、繰返 し通電を経ると近い值になったこととしても表れている。

このようにCSI 試験と SULTAN 試験で繰返し通電特性に 違いが現れた原因について、以下のように考察する。ま ず、繰返し通電や昇温・再冷却で $T_{c s}$ が上昇する理由は、 それらが素線内部の $\mathrm{Nb}_{3} \mathrm{Sn}$ の歪みを緩和するためと言われ ている。しかし、複雑な撚線内で各素線がどのような変形 を受けて歪みが緩和されるのか、具体的なメカニズムはよ く分かっていない。ただ、これに関連すると思われるもの として、小黒らが「熱処理後の $\mathrm{CuNb}$ 補強材 $\mathrm{Nb}_{3} \mathrm{Sn}$ 素線に 適正な事前曲げ歪みを繰返し加えることで、 $\mathrm{Nb}_{3} \mathrm{Sn}$ に加 わっていた圧縮歪みが緩和され、より小さい引張歪みで臨 界電流がピークとなり、さらにそのピーク值も向上した」 と報告しており、これは $\mathrm{Nb}_{3} \mathrm{Sn}$ の 3 次元的な歪み（1 方向 のEではなく 3 方向の $\varepsilon_{x}, \varepsilon_{y}, \varepsilon_{z}$ で考える) の緩和に起因する

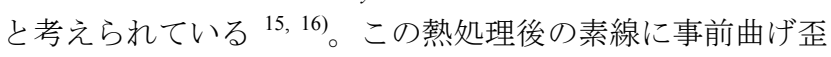
みを繰返し加える方法を用いて杉本らが然線を製作し ${ }^{17) 、}$

実際に $25 \mathrm{~T}$ 無冷媒マグネットーの適用にも成功したことを 淡路らが報告している ${ }^{18)}$ 。CS 用素線の場合は補強材が無 いため「(過剩でない) 適正な変形」の限度が小さいと思 われるが、おそらく Fig. 7 に示した繰返し通電や昇温・再 冷却による $T_{c s}$ の上昇も、これと同様の現象ではないかと 思われる。この「適正な変形」の加わり方は、CSI 試験で は通電によってフープ歪みが加わる分、CSI 試験と SULTAN 試験で異なる。この違いが繰返し通電特性の違い に繋がったと思われ、その考え方の概念図を Fig. 8 に示 す。まず、SULTAN 試験に用いた導体は CSI 試験に用いた 導体と隣接した部位から採取しているので、最初に泠却し ただけの通電する前の撚線の状態は、CSI 試験も SULTAN 試験も同じだと考えられる。しかし、通電した際、

SULTAN 試験での電磁力は撚線を横方向（Fig. 2 の $r$ 方 向）に圧縮するだけなのに対し、CSI 試験ではさらにフー プカによる撚線の長手方向（Fig. 2 の方向）の約 $0.08 \%$ の 伸びも重畳する。したがって、SULTAN 試験に比べて CSI 試験の方が $T_{c s}$ を上昇させる「適正な変形」が多く加わっ たため、フープ歪みによる $T_{c s}$ 上昇分 $(0.5 \mathrm{~K})$ を考慮して も、初回通電で CSI 試験の $T_{c S}$ は SULTAN 試験よりも $0.21 \mathrm{~K}$ 高くなったと考えられる。例えば、導体の熱処理時 には素線同士が若干焼結するが、CSI 試験では撚線の長手 方向の伸長（フープ歪み）がこの焼結を初回通電時から剥 がし、より多くの「適正な変形」が加わったのかも知れな い。なお、CSI 試験では 50 回の繰返し通電で $\Delta T_{c s}=0.02 \mathrm{~K}$ と非常に小さかったのに対し、SULTAN 試験では $\Delta T_{c s}=0.14 \mathrm{~K}$ と急上昇したことから、CSI 試験に比べて SULTAN 試験は初回通電での撚線の状態がまだ安定的では なく適正な変形を加える余地が大きかったと思われる。そ して Fig. 7 に示すように、繰返し通電や昇温・再冷却によ

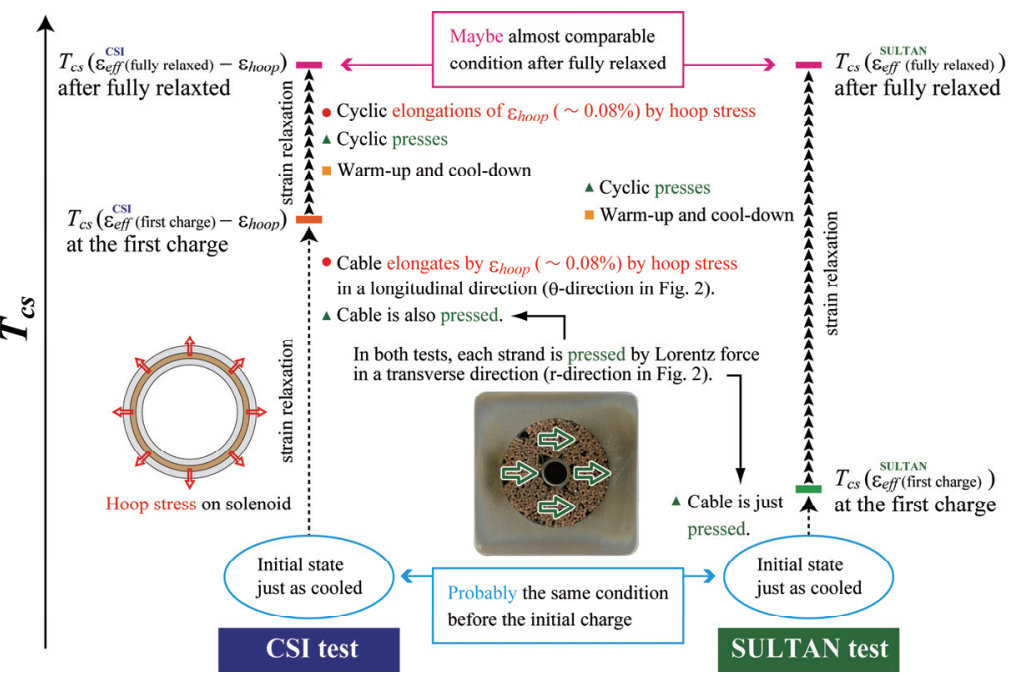

Fig. 8 Schematic image of $T_{c s}$ increase during the CSI test and SULTAN test.

る $T_{c s}$ の上昇幅 $\left(\Delta T_{c s}\right)$ には限度があるため、その限界に達 した状態（歪みの緩和が十分に進んだ状態）に至ると、 CSI 試験と SULTAN 試験の $T_{c S}$ は（フープ歪みの分を考慮 すれば）同等の值になったものと思われる。

導体内の $\mathrm{Nb}_{3} \mathrm{Sn}$ の歪みを非破壊で測定する方法として、 J-PARC の中性子線を用いた解析がある ${ }^{19}$ 。。この時の解析 対象は、 1 次から 4 次の撚りピッチを短くする前の導体 だった。撚りピッチを短くした導体での繰返し通電や昇 温・再冷却による $T_{c s}$ の上昇のメカニズムを調べる場合 も、J-PARC での中性子線を用いた解析などが有効と考え られ、今後も研究を進めて行く。

\section{4. 電磁力の分流開始温度への影響}

\section{1 評価方法}

$\mathrm{Nb}$ - $\mathrm{Ti}$ 素線や $\mathrm{Nb}_{3} \mathrm{Al}$ 素線に比べて $\mathrm{Nb}_{3} \mathrm{Sn}$ 素線は歪みによ る臨界電流 $\left(I_{c}\right)$ の低下が大きいことから、 $\mathrm{Nb}_{3} \mathrm{Sn}$ 撚線の 臨界電流は素線 $I_{c}$ の合計值を下回り、 $T_{c s}$ も低下寸ることが 観測されている。これは撚線に加わる電磁力が素線を変形 させるためであり、CSI 試験では Fig. 2 における $r$ 方向の 電磁力 $\left(F_{r}\right)$ が $T_{c s}$ を低下させると考えられる。この電磁力 の $T_{c S}$ への影響度合いを調べるために、IM 条件や SULTAN 模擬条件、 $\mathrm{EOB}$ 条件の他に、より低い電磁力やより高い電 磁力の下での $T_{c s}$ を測定した。ただし、より高い電磁力を 加える過負荷試験 $\left(13 \mathrm{~T}, 50 \mathrm{kA}\right.$ と $13 \mathrm{~T}, 55 \mathrm{kA}$ での $T_{c s}$ 測 定）は、CS の本来の運転を超えた強い電磁力であるた め、繰返し通電後にのみ実施した。

電磁力による $T_{c s}$ への影響の度合いを定量的に評価する 方法として、素線の $I_{c}$ の磁場 $B$, 温度 $T$, 歪み $\varepsilon$ 特性の式 $\left(I_{c}(B, T, \mathcal{E})\right.$ の式) を用い、撚線の $T_{c s}$ の増減を歪みの増減と して表現する方法がある。ジャケット管との熱収縮差によ る熱歪み $\left(\varepsilon_{t h}\right) 、 \mathrm{CSI}$ 試験の場合はフープ歪み $\left(\varepsilon_{h o o p}\right) 、 さ$ 
らに電磁力による $I_{c}$ や $T_{c s}$ の低下に相当する分を追加の歪 み $\left(\varepsilon_{\text {extra }}\right)$ とし、これら全てを包含する歪みを有効歪み $\left(\varepsilon_{\text {eff }}\right)$ と考える $\left(\varepsilon_{\text {eff }}=\varepsilon_{t h}+\varepsilon_{\text {hoop }}+\varepsilon_{\text {extra }}\right)$ 。導体には磁場分布が あるため、電圧タップ間の単位長さあたりの電圧 $(E)$ を 式(1)によって計算する ${ }^{20-23)}$ 。

$$
E(T)=\frac{E_{0}}{L A} \int_{L} \int_{A}\left(\frac{I_{o p}}{I_{c}\left(B, T, \epsilon_{e f f}\right)}\right)^{n} d A d z
$$

ここで、 $E_{0}$ は $10 \mu \mathrm{V} / \mathrm{m} （ I_{c}$ を定義する際の単位長さあたり の電圧と同じ值)、 $L$ は電圧タップ間の長さ、 $A$ は撚線の断 面積、 $I_{o p}$ は導体内の素線 1 本あたりの通電電流である。さ らに、 $T_{c s}$ 測定試験で $T$ に対する $E$ の試験データが複数点得 られるが、これをフィッティングするための $n$ 值も式(1)に 含まれる（CS 用素線の $n$ 值は 60 程度だが、式(1)における 撚線の $n$ 值は 7 程度になる)。式(1)の積分空間内で $\varepsilon_{\text {eff }}, T, n$ が均一と仮定すれば、 $\varepsilon_{\text {eff }}$ と $n$ をパラメータとして、T,Eの 試験データとの誤差が最も小さくなる組み合わせを決定で きる。

式(1)にも用いている $\mathrm{Nb}_{3} \mathrm{Sn}$ 素線の $I_{c}(B, T, \varepsilon)$ の式は、以前 から Summers らの式 ${ }^{24)}$ がよく使われて来たが、広い $B, T, \varepsilon$ の範囲に対して実際の $\mathrm{Nb}_{3} \mathrm{Sn}$ 素線の測定データにうまく フィッティング出来ない場合があった。その後、Taylor と Hampshire が測定データをよくフィッティング出来る式 ${ }^{25}$ を提案したものの、フィッティングパラメータが多いた め、測定データからフィッティングパラメータの值を決定 する際に扱いづらかった（決定する值の一意性が低かっ た)。さらに後、Bottura と Bordini がフィッティングパラ メータを少なくしつつ、測定データをよくフィッティング 出来る式 ${ }^{26)}$ を提案した。これを式(2), (3)に示す。

$$
I_{c}(B, T, \epsilon)=\frac{C}{B} \cdot s \cdot\left(1-t^{1.52}\right)\left(1-t^{2}\right) b^{p}(1-b)^{q}
$$

ここで、C, $p, q$ はフィッティングパラメータの一部であ り、 $s, t, b$ は下式の通りである。

$$
\begin{gathered}
b=\frac{B}{B_{c 2}^{*}} \quad, \quad B_{c 2}^{*}(T, \epsilon)=B_{c 20 \text { max }}^{*} \cdot s \cdot\left(1-t^{1.52}\right) \\
t=\frac{T}{T_{c}^{*}}, \quad T_{c}^{*}(B, \epsilon)=T_{c 0 \max }^{*} \cdot s^{\frac{1}{3}} \cdot\left(1-\frac{B}{B_{c 2}^{*}(0, \epsilon)}\right)^{\frac{1}{1.52}} \\
s(\epsilon)=1+\frac{C_{a 1}\left(\sqrt{\epsilon_{\text {shift }}^{2}+\epsilon_{0, a}^{2}}-\sqrt{\left(\epsilon-\epsilon_{\text {shift }}\right)^{2}+\epsilon_{0, a}^{2}}\right)-C_{a 2} \epsilon}{1-C_{a 1} \epsilon_{0, a}} \\
\epsilon_{\text {shift }}=\frac{C_{a 2} \epsilon_{0, a}}{\sqrt{C_{a 1}^{2}-C_{a 2}^{2}}}, \quad \epsilon=\epsilon_{\text {applied }}-\epsilon_{\max }
\end{gathered}
$$

式(2), (3)が提案されて以降、ITER では TF 用素線及び CS 用素線に対して専らこの式を用いて評価されるようになっ た。本 CSI 試験の解析でも式(2)，(3)を用いており、そのパ ラメータ值を Table 1 に示す。素線の $I_{c}$ の測定データから パラメータ值を決定するには、Powell の方法（数值解析手
Table $1 I_{c}(B, T, \varepsilon)$ equation parameters of a $\mathrm{Nb}_{3} \mathrm{Sn}$ strand in the CSI conductor

\begin{tabular}{|c|c|c|}
\hline Parameter & Value & Meaning \\
\hline$C$ & 21002 & Scaling constant \\
\hline$B^{*}{ }_{C 20 \max }$ & 29.39203 & Upper critical field at $T=0, \varepsilon=0$ \\
\hline$T^{*}{ }_{C 0 \max }$ & 16.4817 & Critical temperature at $B=0, \varepsilon=0$ \\
\hline$p$ & 0.55565 & $\begin{array}{c}\text { Low-field exponent of the pinning } \\
\text { force }(p \doteqdot 0.5)\end{array}$ \\
\hline$q$ & 1.6980 & $\begin{array}{c}\text { High-field exponent of the pinning } \\
\text { force }(q \doteqdot 2)\end{array}$ \\
\hline$C_{a 1}$ & 45.73983 & Strain fitting constant \\
\hline$C_{a 2}$ & 4.43056 & Strain fitting constant \\
\hline$\varepsilon_{0, a}$ & 0.00232 & Residual strain component \\
\hline$\varepsilon_{\max }$ & 0.00061 & $\begin{array}{c}\text { Tensile strain at which the maximum } \\
\text { critical properties are reached }\end{array}$ \\
\hline
\end{tabular}

法) やソフトウェア（Origin や Igor など）のデータ分析機 能などを用いる。なお、 $\mathcal{E}$ は式(2)の引数であるから、式(2) と Table 1 のパラメータ值を用いて何らかの解析を行う場 合、式(3)の最後 $\left(\varepsilon=\varepsilon_{\text {applied }}-\varepsilon_{\text {max }}\right)$ に出て来る $\varepsilon_{\text {applied }}$ と $\varepsilon_{\text {max }}$ は使用しない。これら $\varepsilon_{\text {applied }}$ と $\varepsilon_{\text {max }}$ は、Table 1 のパラメー 夕值を決定する際にのみ用いるものである。Table 1 のパラ メータ值を決めるための試験では、素線を歪み印加用治具 27-29)にはんだ付けし、 $B, T$ と歪み $\varepsilon_{\text {applied }}$ (治具を用いて素線 に印加した歪み）を様々に変えて $I_{c}$ の測定データを取る。 このとき、同一の $B, T$ において $I_{c}$ が最大となるときの $\varepsilon_{\text {applied }}$ を $\varepsilon_{\max }$ (ほとんどの場合で正值) とする。 $\varepsilon_{\max }$ の值 は、素線をはんだ付けした歪み印加用治具の材質やはんだ 付けする際の条件などに依存するため、これらの依存性を 除外するために、 $\varepsilon=0$ で $I_{c}$ が最大となるようにゼロ点をシ フトする $\left(\varepsilon=\varepsilon_{\text {applied }}-\varepsilon_{\text {max }}\right)$ 。このゼロ点調整された歪み $\varepsilon$ は intrinsic strain と呼ばれる。

式(1)〜(3)では素線長手方向の歪み $\varepsilon$ (longitudinal strain や axial strain と呼ばれる）だけを考えているので、3.3 節の $\left\lceil\mathrm{Nb}_{3} \mathrm{Sn}\right.$ の 3 次元的な歪みの緩和」を正確に評価するには 十分ではない。例えば $\varepsilon$ を $z$ 方向 $\left(\varepsilon_{z}\right)$ とし、 $\varepsilon_{z}$ が一定だっ たとしても、仮に $\varepsilon_{x}$ や $\varepsilon_{y}$ が緩和されれば（絶対值が小さく なれば） $I_{c} や T_{c s}$ は高くなると推測される。その高くなった $I_{c}$ や $T_{c s}$ に対して式(1)〜(3)を用いて解析すれば、「Eが緩和 された（絶対值が小さくなった）」と評価されることにな る。

\section{2 電磁力に対する有効歪み}

繰返し通電前と繰返し通電後の、 $r$ 方向の電磁力 $\left(F_{r}\right)$ に対する有効歪み $\left(\varepsilon_{\text {eff }}\right)$ を Fig. 9 に示す $\left(\varepsilon_{\text {eff }}\right.$ は $\varepsilon_{\text {hoop }}$ と同じ $\theta$ 方向の歪みである)。ここで、 $F_{r}>0$ の領域では拡張方向 のフープ歪み $\left(\varepsilon_{\text {hoop }}>0\right)$ が加わっており、 $F_{r}<0$ の領域で は圧縮方向のフープ歪み $\left(\varepsilon_{\text {hoop }}<0\right)$ が加わっている。ま た、 $\varepsilon_{\text {eff }}$ から Fig. 4 の $\varepsilon_{\text {hoop }}$ を差し引いたデータ $\left(\varepsilon_{\text {eff }}-\varepsilon_{\text {hoop }}\right)$ と、SULTAN 試験で得られた $\varepsilon_{e f f}$ も Fig. 9 に合わせて示して 


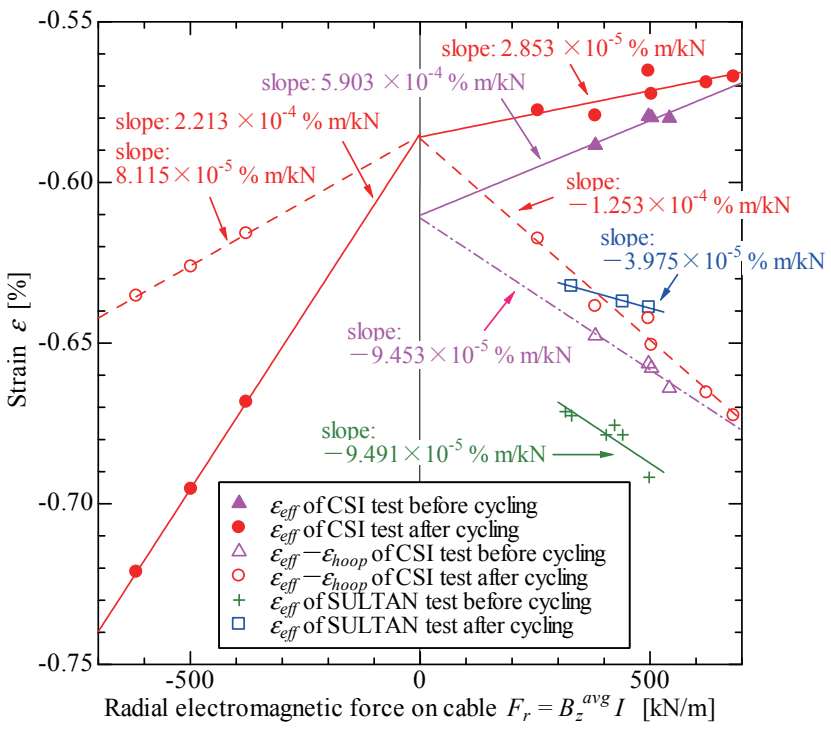

Fig. 9 Strain against radial electromagnetic force on cable before and after cycling.

\section{おり、これらに関しては次節で考察する。}

CSI 試験において、 $F_{r}>0$ の領域では、繰返し通電の前 も後も、電磁力が大きくなるほど $\varepsilon_{\text {eff }}$ の絶対值が小さくなっ ている。これは、正のフープ歪みによる $T_{c s}$ の上昇が、電 磁力による $T_{c s}$ の低下を上回った結果と考えられる。フー プ歪みを除いた $\varepsilon_{e f f}-\varepsilon_{\text {hoop }}$ では、電磁力に対して歪みの絶対 值が大きくなっており、やはり $F_{r}$ が $T_{c s}$ を低下させている ことが分かる。なお、 $F_{r}$ に対する $\varepsilon_{\text {eff }}$ の勾配は、繰返し通電 前が $5.903 \times 10^{-5} \% \mathrm{~m} / \mathrm{kN}$ だったのに対し、繰返し通電後は $2.853 \times 10^{-5} \% \mathrm{~m} / \mathrm{kN}$ と小さくなっており、電磁力による $T_{c s}$ の低下度合いが、繰返し通電を経て大きくなった可能性を 示唆している。ただ、繰り返し通電前のデータは $F_{r}$ があま り広くない範囲で 4 点しかなく、繰り返し通電後のデータ にはばらつきが大きいため、まだ不確定な要素を含んでい る。例えば、繰返し通電前の $\varepsilon_{\text {eff }}$ のデータは $F_{r}=381 \sim$ $542 \mathrm{kN} / \mathrm{m}$ の範囲なのに対し、繰返し通電後は $F_{r}=256 \sim$ $682 \mathrm{kN} / \mathrm{m}$ と約 2.6 倍も広く、仮に繰返し通電前と同等の $F_{r}$ の範囲で繰返し通電後の $\varepsilon_{e f f}$ を見れば、 $F_{r}$ に対する $\varepsilon_{e f f}$ の勾 配は $8.323 \times 10^{-5} \% \mathrm{~m} / \mathrm{kN} （ F_{r}=381 \sim 503 \mathrm{kN} / \mathrm{m}$ の場合）また は $4.104 \times 10^{-5} \% \mathrm{~m} / \mathrm{kN} \quad\left(F_{r}=381 \sim 623 \mathrm{kN} / \mathrm{m}\right.$ の場合）とな り、両者の平均值は $6.213 \times 10^{-5} \% \mathrm{~m} / \mathrm{kN}$ となる。この值は 繰返し通電前の勾配 $\left(5.903 \times 10^{-5} \% \mathrm{~m} / \mathrm{kN}\right)$ とほぼ同じなの で、この場合、繰返し通電前後で電磁力による $T_{c s}$ の低下 度合いは変わらなかったと言える。やはり今後はできるだ け広い $F_{r}$ の範囲で多くの測定データを取ることに努めると 共に、測定における䛊差幅の適切な評価方法を検討する必 要がある。いずれにせよ、より保守的に考えて、繰返し通 電によって電磁力の影響を受け易くなる可能性を考慮し、 実機 CS の製作（特に熱処理後の施工）やITERに組み込ま れた後の運転では十分に注意を払うべきだと考える。
$F_{r}<0$ の領域では、電磁力が大きくなるほど $\varepsilon_{e f f}$ の絶対值 が大きくなっている。これは、負のフープ歪みによる $T_{c s}$ の低下と、電磁力による $T_{c s}$ の低下が重畳するためであ る。なお、フープ歪みを除いた $\varepsilon_{\text {eff }}-\varepsilon_{\text {hoop }}$ では、 $F_{r}>0$ の側 と $F_{r}<0$ の側で破線同士が概ね対称になり、電磁力による $T_{c s}$ の低下度合いが $F_{r}>0$ の側と $F_{r}<0$ の側で似通っている ことが分かる。

冷却時、撚線がジャケット管との熱収縮差によって受け る熱歪み $\left(\varepsilon_{t h}\right)$ は、単純な一軸モデルで考えれば、Fig. 9 において $F_{r}=0$ まで外挿して得られる歪みに相当する。繰 返し通電前は $\varepsilon_{t h}=-0.611 \%$ であり、繰返し通電後は $F_{r}>0$ 側からの外挿值も $F_{r}<0$ 側からの外挿值も $\varepsilon_{t h}=-0.586 \%$ で 一致した。繰返し通電を経て $\varepsilon_{t h}$ の絶対值が小さくなった理 由は以下のように考えられる。ジャケット管は繰返し通電 によるフープ歪み（約 $0.08 \%$ ）を受けても弾性変形するの みなので（冷間加工履歴と熱処理を経たジャケット材の $4.2 \mathrm{~K}$ での引張試験では、 $0.4 \%$ 歪みまで弾性変形する)、 繰返し通電を経てもジャケット管の剛性は変わらない。し たがって、撚線を一本の棒のように考えるなら、繰返し通 電を経て撚線の弾性係数が上がらない限り、熱歪みは変わ らないはずである。しかし、Fig. 9 から推測される $\varepsilon_{t h}$ は、 導体のマク口な長手方向の寸法から得られる值ではなく、 $\mathrm{Nb}_{3} \mathrm{Sn}$ 素線の超伝導特性から推測された值である。した がって、繰返し通電を経て素線内の $\mathrm{Nb}_{3} \mathrm{Sn}$ に加わっている 歪みが第 3 章で述べたように緩和されるなら、 $\varepsilon_{t h}$ の絶対值 が小さくなったことは理に適っている。このことからも、 繰返し通電が $\mathrm{Nb}_{3} \mathrm{Sn}$ の歪みの緩和に関わっていることを推 測される。

\section{3 SULTAN 試験結果との比較}

SULTAN 試験ではフープ歪みは加わらないので、CSI 試 験の $\varepsilon_{\text {eff }}-\varepsilon_{\text {hoop }}$ と SULTAN 試験の $\varepsilon_{\text {eff }}$ を比較する。繰返し通 電前、SULTAN 試験の $\varepsilon_{\text {eff }}$ は CSI 試験の $\varepsilon_{\text {eff }}-\varepsilon_{\text {hoop }}$ よりも絶対 值で $0.3 \%$ もきい。これは第 3 章で述べたように、 SULTAN 試験では初回通電時の $T_{c s}$ が低いことに対応す

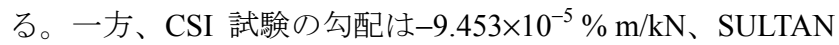
試験の $-9.491 \times 10^{-5} \% \mathrm{~m} / \mathrm{kN}$ で、両試験ともほぼ同じだっ た。したがって、繰返し通電前は、電磁力が $T_{c s}$ を低下さ せる度合いは両試験でほぼ同じだったと言える。

繰返し通電後、SULTAN 試験の $\varepsilon_{\text {eff }}$ が CSI 試験の $\varepsilon_{\text {eff }}-\varepsilon_{\text {hoop }}$ にかなり近づいた。これは第 3 章で述べたよう に、繰返し通電を経て歪みの緩和による $T_{c s}$ の上昇が進行 すると、SULTAN 試験が CSI 試験に近くなったことに対応 する。一方、CSI 試験の勾配は- $1.253 \times 10^{-4} \% \mathrm{~m} / \mathrm{kN}$ であ り、SULTAN 試験の-3.975 $\times 10^{-5} \% \mathrm{~m} / \mathrm{kN}$ よりも大きい。た だ、SULTAN 試験の $\varepsilon_{\text {eff }}$ のデータは $F_{r}=329 \sim 498 \mathrm{kN} / \mathrm{m}$ の範 囲に 3 点しかなく、CSI 試験の $\varepsilon_{\text {eff }}-\varepsilon_{\text {hoop }}$ のデータは $F_{r}$ $=256 \sim 682 \mathrm{kN} / \mathrm{m}$ と約 2.5 倍も広いもののばらつきが大き い。例えば CSI 試験の $\varepsilon_{\text {eff }}-\varepsilon_{\text {hoop }}$ のデータを $F_{r}=381 〜$ 
$503 \mathrm{kN} / \mathrm{m}$ に限って見れば、 $F_{r}$ に対する $\varepsilon_{\text {eff }}-\varepsilon_{\text {hoop }}$ の勾配は $-6.986 \times 10^{-5} \% \mathrm{~m} / \mathrm{kN}$ となり、SULTAN 試験の勾配に近づ く。やはりまだ不確定な要素を含んでおり、今後は SULTAN 試験でもできるだけ広い $F_{r}$ の範囲で多くの測定 データを取ることに努めると共に、測定における誤差幅の 適切な評価方法を検討する必要がある。

\section{4 過去の設計の CS 導体との比較}

1 次から 4 次の撚りピッチを短くする前の導体では、 SULTAN 試験において繰返し通電前の勾配が $-1.920 \times 10^{-4} \% \mathrm{~m} / \mathrm{kN}$ だった ${ }^{6}$ 。したがって、撚りピッチを 短くすることで勾配は半分程度に小さくなり、短い撚り ピッチは繰返し通電による $T_{c s}$ の低下を抑えるだけでな く、電磁力による $T_{c s}$ の低下も抑えていると言える。ま た、撚りピッチを短くする前の導体では、繰返し通電によ り $T_{c s}$ が低下寸るのに伴い、繰返し通電後の $\varepsilon_{\text {eff }}$ は絶対值も 勾配も大きくなり、 $\varepsilon_{t h}$ の絶対值も大きくなる。なお、 SULTAN 試験で繰返し通電を経た導体を日本に返送して解 体し、撚線の状態を観察しているが、撚りピッチを短くす ることで然線の変形は明らかに抑制されていることが分 かっている7)。

また、2000 年に実施した旧 CS インサート・コイルの試 験では、勾配がー $4 \times 10^{-4} \% \mathrm{~m} / \mathrm{kN} 、 \varepsilon_{t h}$ が- $0.35 \%$ と評価されて いる ${ }^{30)}$ 。 $\varepsilon_{t h}$ の絶対值がかなり小さいのは、第 1 章で述べた 通り、ジャケット管に $\mathrm{Nb}_{3} \mathrm{Sn}$ との熱収縮差の小さい Incoloy908 を用いたためである。この導体に使った素線は まだ $I_{c}$ が低かった時代のものであり、素線本数も然りピッ チもジャケット管の材質も本 CSI 導体と異なる。したがっ て、何が大きく寄与したかは明確に言えないが、約 15 年 間の進歩を経て、電磁力による $T_{c s}$ の低下度合いは約 $1 / 4$ に まで減少することができた。

\section{5. 結論}

CSI 試験の分流開始温度 $\left(T_{c s}\right)$ 測定に関し、以下の結論 を得た。

1) アクティブとダミーの一軸歪ゲージを用いた 2 ゲージ 法により、然線に加わる $r$ 方向の電磁力 $\left(F_{r}\right)$ に対す るフープ歪み $\left(\varepsilon_{\text {hoop }}\right)$ を測定した。その勾配は順通電 $\left(\varepsilon_{\text {hoop }}>0\right)$ で $1.55 \times 10^{-4} \% \mathrm{~m} / \mathrm{kN}$ 、逆通電 $\left(\varepsilon_{\text {hoop }}<0\right)$ で $1.39 \times 10^{-4} \% \mathrm{~m} / \mathrm{kN}$ となり、逆通電の方が 1 割小さ かった。勾配が僅かに異なるのは、通電方向による上 下フランジからの $r$ 方向変形の抑制効果の違いが原因 ではないかと推測する。

2) 16000 回の繰返し通電と 3 回の昇温・再冷却の間、IM 条件（13 T, $40 \mathrm{kA）での} T_{c s}$ は $6.71 \mathrm{~K}$ から $6.84 \mathrm{~K}$ の間 で増減した後、 $6.74 \mathrm{~K}$ で一定化した。これにより、設 計值の $5.2 \mathrm{~K}$ に対し $1.5 \mathrm{~K}$ 以上の裕度を維持し続けるこ とを実証した。

3) SULTAN 模擬条件（11.5 T, 45.1 kA）での $T_{c s}$ は、CSI
試験はフープ歪みの影響を考慮すると、繰返し通電が 10000 回以降で SULTAN 試験の結果に近くなった。 10000 回未満は SULTAN 試験の方が低く、特に最初の 通電時はフープ歪みの影響を考慮しても $0.21 \mathrm{~K}$ 低かっ た。これは、SULTAN 試験に比べて CSI 試験はフープ 歪みが加わる分、歪みの緩和による $T_{c s}$ の上昇が初回 通電から大きかったためと考えられる。10000 回を超 える繰返し通電を経ると、CSI 試験も SULTAN 試験も 歪みの緩和が十分に進んで $T_{c s}$ の上昇が頭打ちにな り、この状態では両試験の $T_{c s}$ が同等になったと考え られる。このように考えると、CSI 試験と SULTAN 試 験は整合した結果であると言える。

4) CSI 試験での電磁力 $\left(F_{r}\right)$ に対する有効歪み $\left(\varepsilon_{e f f}\right)$ の 勾配（正值）は、繰返し通電前に比べて繰返し通電後 の方が若干小さくなる $\left(F_{r}\right.$ による $T_{c s}$ の低下度合いが 大きくなる）傾向が見られた。ただ、繰返し通電前に 比べて繰返し通電後の $T_{c s}$ (即ち $\left.\varepsilon_{\text {eff }}\right)$ 測定は非常に広い 範囲（約 2.6 倍）の $F_{r}$ に亘って実施しており、同程度 の $F_{r}$ の範囲に限って比較すれば、繰返し通電前後で勾 配はほぼ同じになるため、単に $F_{r}$ の範囲が異なること に起因する可能性もある。

以上の結果から、現在量産している CS 導体は、ITER に組 み込まれた後、設計值に対して十分な裕度を持って運転で きることを実証した。一方で、繰返し通電を経ると電磁力 による $T_{c s}$ の低下度合いが大きくなる可能性が示唆され た。これは単に $T_{c s}$ を測定した電磁力の範囲や測定データ の数が不十分であったり、測定データのばらつきに起因す るのかも知れないが、より保守的に考えて、実機 CS の製 作（特に熱処理後の施工）や ITER に組み込まれた後の運 転（例えばプラズマ実験のために拡張モードで過負荷な運 転を行う場合）で十分に注意を払う必要がある。また、本 試験により電磁力に対するフープ歪みが定量化され、 $T_{c s}$ ヘ の影響も明らかになった。さらに、導体の品質管理として 行っている SULTAN 試験との比較も行い、繰返し通電回数 が少ない間は SULTAN 試験での $T_{c s}$ は CSI 試験よりも低い が、ある程度の繰返し通電や昇温・再冷却を経ると両者は 同等になる（フープ歪みによる差異は考慮する必要があ る）ことが分かり、両試験は論理的に整合すると考えられ る。

本試験を遂行するに当たり、多大な御支援を頂いた ITER 機構 多田栄介副機構長、原子力機構 那珂核融合研 究所 森雅博所長、草間義紀副所長、奥野清氏、中嶋秀夫 氏に深く感謝致します。

CS インサート・コイルの素線製作はジャパンスーパー コンダクタテクノロジー株式会社（JASTEC）、撚線製作は 三菱電線工業株式会社、ジャケット管製作は神鋼特殊鋼管 株式会社、導体製作は新日鉄住金エンジニアリング株式会 
社、コイル製作は三菱電機株式会社に御協力頂きました。 特に CS 素線・撚線の製作に関しては、2014 年 2 月の雪害 による工場の全壊・半壊など様々な予期せぬトラブルに遭 いながらも、上記 2 社と古河電気工業株式会社及び株式会 社 SH カッパープロダクツが競合他社同士にも拘わらず協 力し合って製作を進めて頂けたことに深く感謝致します。

\section{参 考 文 献}

1) 名原啓博, 諏訪友音, 尾関秀将, 布谷嘉彦, 礒野高明, 高橋 良和，奥野 清 : 「ITER トロイダル磁場コイル用及び中心ソ レノイド用超伝導導体の製作」，プラズマ・核融合学会誌 (2016) (印刷中)

2) Y. Nabara, T. Suwa, H. Ozeki, H. Kajitani, T. Sakurai, T. Hemmi, M. Iguchi, Y. Nunoya, Y. Takahashi, T. Isono, K. Matsui, N. Koizumi, F. Tsutsumi, Y. Uno, M. Oshikiri, K. Shibutani, K. Okuno, Y. Murakami, T. Takano, K. Sedlak, B. Stepanov and P. Bruzzone: "Performance analysis of mass-produced $\mathrm{Nb}_{3} \mathrm{Sn}$ conductor for central solenoid in ITER," IEEE Trans. Appl. Supercond. 26 (2016) 4200705

3) T. Isono, K. Kawano, Y. Nunoya, Y. Takahashi and K. Okuno: “Testing of ITER CS insert coil,” TEION KOGAKU 51 (2016) 97101 (in Japanese) 礒野高明, 河野勝己, 布谷嘉彦, 高橋良和, 奥野 清 :「ITERCS インサート・コイル試験」, 低温工学 51 (2016) 97-101

4) Y. Nunoya, T. Isono, M. Sugimoto, Y. Takahashi, T. Ando, G. Nishijima and CS Model Coil Test Group: "Critical current and sharing temperature of the ITER-CS insert coil" TEION KOGAKU 36 (2001) 354-360 (in Japanese)

布谷嘉彦，礒野高明，杉本誠，高橋良和，安藤俊就，西島元， CS モデル・コイル実験グループ：「ITER-CS インサート・コ イルの臨界電流および分流開始温度」, 低温工学 36 (2001) 354-360

5) T. Hemmi, Y. Nunoya, Y. Nabara, M. Yoshikawa, K. Matsui, H. Kajitani， K. Hamada， T. Isono， Y. Takahashi， N. Koizumi, H. Nakajima, B. Stepanov and P. Bruzzone: "Test results and investigation of $T_{c s}$ degradation in Japanese ITER CS conductor Samples," IEEE Trans. Appl. Supercond. 22 (2012) 4803305

6) Y. Nabara, T. Suwa, H. Ozeki, H. Kajitani, T. Sakurai, T. Hemmi, M. Iguchi, Y. Nunoya, Y. Takahashi, T. Isono, K. Matsui, N. Koizumi, F. Tsutsumi, Y. Uno, M. Oshikiri, K. Shibutani, K. Okuno, Y. Murakami, T. Takano, K. Sedlak, B. Stepanov and P. Bruzzone: "Examination of $\mathrm{Nb}_{3} \mathrm{Sn}$ conductors for ITER central solenoids," IEEE Trans. Appl. Supercond. 23 (2013) 4801604

7) Y. Nabara, T. Hemmi, H. Kajitani, H. Ozeki, T. Suwa, M. Iguchi, Y. Nunoya, T. Isono, K. Matsui, N. Koizumi, F. Tsutsumi, Y. Uno, M. Oshikiri, K. Shibutani, Y. Takahashi, K. Okuno, Y. Murakami, T. Miyatake, M. Sugimoto, A. Takagi, Y. Nakada, K. Miyashita, K. Sedlak, B. Stepanov and P. Bruzzone: "Impact of cable twist pitch on $T_{c s}$-degradation and $\mathrm{AC}$ loss in $\mathrm{Nb}_{3} \mathrm{Sn}$ conductors for ITER central solenoids," IEEE Trans. Appl. Supercond. 24 (2014) 4200705

8) T. Suwa, Y. Nabara, H. Ozeki, T. Hemmi, T. Isono, Y. Takahashi, K. Kawano, M. Oshikiri, F. Fumiaki， K. Shibutani， Y. Nunoya, K. Okuno, Ki-Hong Sim, P. Park, K. Jang, J. Lee, I. Han, S. Kwon, S. Park, K. Sedlak, B. Stepanov and P. Bruzzone: "Analysis of internal-tin $\mathrm{Nb}_{3} \mathrm{Sn}$ conductors for ITER central solenoid," IEEE Trans. Appl. Supercond. 25 (2015) 4201704

9) T. Kato, K. Hamada, K. Yamamoto, I. Watanabe, K. Ishio, T. Ando, H. Tsuji, T. Abe, K. Kikuchi, N. Minakawa, M. Tsuchiya, M. Tsubota, Y. Katayama, S. Ikeda, H. Ogata, T. Fujioka and A. Osaki: "Avoidance method study for SAGBO cracking during heat treatment of a ITER CS model coil conductor using INCOLOY 908 Jacket," Adv. Cryo. Eng. 44 (1998) 9-15

10) T. Ando: " $\mathrm{Nb}_{3} \mathrm{Sn}$ conductor development for fusion power applications," TEION KOGAKU 39 (2004) 383-390 (in Japanese) 安藤俊就:「核融合用 $\mathrm{Nb}_{3} \mathrm{Sn}$ 導体の開発」, 低温工学 39 (2004) 383-390

11) K. Hamada, H. Nakajima, K. Kawano, K. Takano, F. Tsutsumi, K. Okuno, T. Suzuki and N. Fujitsuna: "Optimization of JK2LB chemical component for ITER central solenoid jacket material," TEION KOGAKU 41 (2006) 131-138 (in Japanese)

濱田一弥, 中嶋秀夫, 河野勝己, 高野克敏, 堤文明, 奥野清, 鈴木富男, 藤綱宣之 : 「ITER 中心ソレノイド用コンジット材 料 JK2LB の成分最適化」, 低温工学 41 (2006) 131-138

12) K. Hamada， H. Nakajima，K. Kawano，K. Takano, F. Tsutsumi, K. Okuno, T. Suzuki and N. Fujitsuna, "Optimization of JK2LB chemical composition for ITER central solenoid conduit material," Cryogenics, 47 (2007) 174-182

13) Y. Takahashi, Y. Nabara, H. Ozeki, T. Hemmi, Y. Nunoya, T. Isono, K. Matsui, K. Kawano, M. Oshikiri, Y. Uno, F. Tsutsumi, K. Shibutani, T. Kawasaki, K. Okuno, Y. Murakami, M. Tani, G. Sato, Y. Nakata and M. Sugimoto: "Cabling technology of $\mathrm{Nb}_{3} \mathrm{Sn}$ conductor for ITER central solenoid," IEEE Trans. Appl. Supercond. 24 (2014) 4802404

14) M. Sugimoto, H. Nakajima, Y. Tsuchiya, H. Kubo and CS Model Coil Test Group: "Experimental results of CS model coil -Mechanical performance-," TEION KOGAKU 36 (2001) 336343 (in Japanese)

杉本 誠, 中嶋秀夫, 土屋佳則, 久保博篤, CS モデル・コイ ル実験グループ：「CS モデル・コイル実験結果一機械特性一」, 低温工学 36 (2001) 336-343

15) H. Oguro, S. Awaji, K. Watanabe, M. Sugimoto and H. Tsubouchi: "Prebending effect for mechanical and superconducting properties of Nb-rod-processed $\mathrm{Cu}-\mathrm{Nb}$ internal-reinforced $\mathrm{Nb}_{3} \mathrm{Sn}$ wires," IEEE Trans. Appl. Supercond. (2014) 8401004

16) M. Sugimoto, H. Tsubouchi, S. Endoh, A. Takagi, K. Watanabe, S. Awaji and H. Oguro: "Development of Nb-rod-method $\mathrm{Cu}-\mathrm{Nb}$ reinforced $\mathrm{Nb}_{3} \mathrm{Sn}$ rutherford cables for react-and-wind processed wide-bore high magnetic field coils," IEEE Trans. Appl. Supercond. (2015) 6000605

17) M. Sugimoto, H. Tsubouchi, K. Katayama, S. Endoh, A. Takagi, H. Shimizu, K. Watanabe, S. Awaji and H. Oguro: "Summary of high-strength $\mathrm{Nb}_{3} \mathrm{Sn}$ rutherford cable developments for a cryogenfree $25 \mathrm{~T}$ superconducting magnet," Abstracts of CSJ Conference 92 (2015) 171

杉本昌弘, 坪内宏和, 片山功多, 遠藤 壮, 高木 亮, 渡辺 和雄, 淡路 智, 小黒英俊 : 無冷媒 $25 \mathrm{~T}$ 超伝導マグネット 用の高強度 $\mathrm{Nb}_{3} \mathrm{Sn}$ ラザフォードケーブル開発のまとめ」, 第 92 回 2015 年度秋季低温工学・超電導学会講演概要集 (2015) 171

18) S. Awaji, H. Oguro, K. Watanabe, H. Miyazaki, T. Tosaka, S. Hanai and S. Ioka: "Performance test of $25 \mathrm{~T}$ cryogen-free 
superconducting magnet (Combination test)," Abstracts of CSJ Conference 92 (2015) 174

淡路 智, 小黒英俊, 渡辺和雄, 宮崎寛史, 戸坂泰造, 花 井哲, 井岡 茂:「無冷媒 $25 \mathrm{~T}$ 超伝導マグネットの励磁試 験 (組み合せ試験)」, 第 92 回 2015 年度秋季低温工学・超 電導学会講演概要集 (2015) 174

19) T. Hemmi, S. Harjo, Y. Nunoya, H. Kajitani, N. Koizumi, K. Aizawa, S. Machiya and K. Osamura: "Neutron diffraction measurement of internal strain in the first Japanese ITER CS conductor sample," Supercond. Sci. Technol. 26 (2013) 084002

20) D. Bessette: "Modeling techniques for correcting measured data on the ITER toroidal field insert coil," IEEE Trans. Appl. Supercond. 14 (2004) 1418-1422

21) D. Bessette: "DC performance analysis of $\mathrm{NbTi}$ and $\mathrm{Nb}_{3} \mathrm{Sn}$ ITER relevant cable in conduit conductor," IEEE Trans. Appl. Supercond. 15 (2005) 1403-1406

22) D. Bessette and N. Mitchell: "Review of the results of the ITER toroidal field conductor R\&D and qualification,” IEEE Trans. Appl Supercond., 18 (2008) 1109-1113

23) M. Breschi, D. Bessette and A. Devred: "Evaluation of effective strain and $n$-value of ITER TF conductor samples," IEEE Trans. Appl. Supercond. 21 (2011) 1969-1973

24) L.T. Summers, M.W. Guinan, J.R. Miller and P.A. Hahn: “A model for the prediction of $\mathrm{Nb}_{3} \mathrm{Sn}$ critical current as function of field, temperature, strain, and radiation damage," IEEE Trans. Magn. 27 (1991) 2041-2044

25) D.M. Taylor and D.P. Hampshire: "The scaling law for the strain dependence of the critical current density in $\mathrm{Nb}_{3} \mathrm{Sn}$ superconducting wires," Supercond. Sci. Technol. 18 (2005) S241-S252

26) L. Bottura and B. Bordini: “ $J_{\mathrm{c}}(B, T, \varepsilon)$ parameterization of the ITER $\mathrm{Nb}_{3} \mathrm{Sn}$ production," IEEE Trans. Appl. Supercond. 19 (2009) 1521-1524

27) C.R. Walters, I.M. Davidson and G.E. Tuck: "Long sample high sensitivity critical current measurements under strain," Cryogenics 26 (1986) 406-412

28) A. Godeke, M. Dhalle, A. Morelli, L. Stobbelaar, H. van Weeren, H. J. N. van Eck, W. Abbas, A. Nijhuis, A. den Ouden and B. ten Haken: "A device to investigate the axial strain dependence of the critical current density in superconductors," Rev. Scientific Instrum. 75 (2004) 5112-5118

29) Y. Nunoya, T. Isono, N. Koizumi, K. Hamada, Y. Nabara and K. Okuno: "Development of strain-applying apparatus for evaluation of ITER $\mathrm{Nb}_{3} \mathrm{Sn}$ strand," IEEE Trans. Appl. Supercond. 17 (2007) 2588-2590

30) N. Mitchell: "Summary, assessment and implications of the ITER model coil test results," Fusion Eng. Des. 66-68 (2003) 971-993
名 原 啓 博 1975 年 7 月生。1998 年東京工業大学工学部 機械宇宙学科卒業。2002 年同大学院総合理工学研究科博士後期 課程修了。2002 年日本原子力研究所 (現 日本原子力研究開発機 構）博士研究員を経て 2003 年より同研究所研究員。主に核融合 炉用超伝導導体の開発に従事。低温工学・超電導学会、プラズ マ・核融合学会、電気化学会会員。工学博士。

齊 藤 徹 1971 年 6 月生。2008 年(株) 神戸工業試験場 に入社。現在、日本原子力研究開発機構 超伝導コイル試験グ ループ所属。主に極低温構造材料の研究開発に従事。日本材料学 会、低温工学・超電導学会会員。工学博士。

諏 訪 友 音 1987 年 6 月生。2013 年東北大学工学部応用 物理学専攻 博士前期課程修了。日本原子力研究開発機構 超伝導 コイル試験グループ所属。主に核融合炉用超伝導導体の研究開発 に従事。低温工学・超電導学会、応用物理学会会員。

尾 関 秀 将 1987 年 12 月生。2010 年名古屋大学工学部 物理工学科卒業。2012 年同大学院工学研究科博士前期課程（工 ネルギー理工学専攻）修了。同年独立行政法人（現：国立研究開 発法人) 日本原子力研究開発機構勤務。主に核融合炉用超伝導導 体開発に従事。低温工学・超電導学会会員。

布 谷 嘉 彦 1967 年 7 月生。1991 年立教大学理学部物理 学科卒業。1993 年同大学院理学研究科修士課程修了。日本原子 力研究開発機構に勤務し、主に核融合炉用超伝導磁石の研究開発 に従事。低温工学・超電導学会会員。工学博士。

高 橋 良 和 1952 年 1 月生。1980 年日本原子力研究所入 所。現在、日本原子力研究開発機構 超伝導コイル試験グループ 所属。主に超伝導パルスコイル、導体の研究開発に従事。低温工 学・超電導学会、日本物理学会、電気学会会員。理学博士。

河 野 勝 己 1964 年 7 月生。1983 年日本原子力研究所 (現在：日本原子力研究開発機構）に入所。現在、核融合研究開 発部門 超伝導コイル試験グループ サブ・リーダー。主に大型超 伝導コイル、極低温ヘリウム冷凍機及び極低温. 用構造材料の研究 開発に従事。低温工学・超電導学会会員。

礒 野 高 明 1963 年 5 月生。1988 年日本原子力研究所入 所。現在、日本原子力研究開発機構 超伝導コイル試験グループ 所属。主に、超伝導コイル、 $\mathrm{Nb}_{3} \mathrm{Sn}$ 導体、高温超伝導導体及び電 流リードの研究開発に従事。低温工学・超電導学会、電気学会会 員。工学博士。 